\title{
粒子系モデルによる衣服圧推定に関する研究
}

\author{
信州大学繊維学部 堀場洋輔・乾 滋・高寺政行・清水義雄

\section{Study on Prediction of Clothing Pressure by using Particle Model}

\author{
Yosuke Horiba, Shigeru Inui, Masayuki Takatera, and Yoshio Shimizu
}

Faculty of Textile Science \& Technology, Shinshu University, 3-15-1 Tokida, Ueda, Nagano 386-8567, Japan

\begin{abstract}
In this paper, we discussed the particle based mechanical model for numerical simulation of clothing pressure. Human body and clothing were represented as an elastic body by particle system, collision between human body and clothing was represented by impulse force based model. The two simulations were conducted to evaluate the validity of the suggested model. In the first simulation, clothing pressure on the elastic cylinder covered with cloth was predicted to evaluate the precision of static clothing pressure prediction. As a result, it was confirmed that it had the accuracy of $0.08 \mathrm{kPa}$, but there was a room for improvement to predict on the edge of cloth. Although it is considered that the mesh resolution (particle distance) caused the problem, it is important to decide a suitable mesh resolution for purpose because it is directly with calculation time. In the second simulation, we conducted the simulation that winding elbow with sleeve to evaluate the precision of dynamic clothing pressure prediction. As a result, it was observed that clothing pressure changed with elbow flexion. However it was not able to obtain the accurate result caused by numerical instability in the case of fast elbow flexion. It is considered that time step and collision model between clothing and human body on the simulation caused numerical instability. Improvement and implementation of the simulation considering whole body motion for dynamic clothing pressure prediction are our future work.
\end{abstract}

(Received 14 June, 2010 ; Accepted 7 October, 2010)

\section{1. 緒 言}

着衣時に衣服と人体との間に生じる衣服圧は, その発 生原因として, （I）衣服重量，（II）衣服の緊迫(hoop tension), (III) 動作に伴う人体形状の変形等が知られてい る [1]. 数多くの先行研究から衣服圧は衣服の着心地と密 接に関係していることが明らかになっており，そのため 衣服設計において衣服圧を考慮することが非常に重要と 考えられている[2-7].

衣服圧を適切に考慮した設計を行なう場合，衣服圧の 計測は不可欠であり, 現在のところ計測方法として, 直 接方式と間接方式が提案されている. 直接方式は, エア パックと呼ばれる小さな袋状のセンサにひずみゲージを 接続し，ひずみゲージの抵抗変化から衣服圧を計測する 方法である $[8]$. この方式は小型で高感度のセンサが多数 開発されているため, 容易に衣服圧を計測することが可 能であるが, 計測誤差が少なくないことや, 有線のため 動作や計測部位が制約されることなどの問題点が考えら れる. 一方, 間接方式は, Kirkらによって提案された, 衣服の張力と対象部位の曲率半径から間接的に衣服圧を 求める方法である [9]. この方法は対象部位にセンサを装
着する必要はないものの, 人体のような複雑な形状に対 しては近似的な值になることや, 上記 (III)のような動作 に伴い経時的に変化する衣服圧の計測には不向きである こと等が問題点として挙げられる.

そこで本研究では, コンピュータシミュレーションに より衣服圧を推定することを目的とする. シミュレーショ ンによる衣服圧の推定が有利な点として, センサを装着 する必要がないため, あらゆる条件・部位で推定が可能 なことや，CAD 技術と連携させることによって設計段階 での衣服圧の予測が可能になることが予想される.

これまでに発表された関連研究としては, 有限要素法 による衣服圧の予測が知られている[10-13]。たとえば庭 屋らは, 衣服を多数の弾性三角形要素で近似し, 人体形 状を拘束条件として衣服のポテンシャルエネルギーの平 衡状態を求め, その時の接触抗力から衣服圧を推定して いる. 翻って本研究では, 有限要素モデルの代わりに粒 子系モデルを用いる．粒子系モデルはコンピュータグラ フィックスの分野で炎や水など複雑な挙動を示す流体を 表現するために提案された手法であり，粒子間の相互関 係を対象に応じて定義することにより様々な現象のモデ ル化が可能である[14-16]. 筆者らは先行研究において布 
に粒子系モデルを適用し, 布の変形挙動を精密に予測し ている[17-19]. 有限要素モデルと粒子系モデルの比較に ついては, 文献[20]で詳細に報告されているため本稿で は割愛するが, 粒子系モデルの利点として, 実装が容易 なことと, 計算時間が比較的短いことを強調しておきた い.

人体モデルもまた, 本研究が上記の先行研究と異なる 点である. 庭屋らは前述のように, 人体形状を境界条件 として扱っており, 衣服圧算出の際には人体の弾性係数 を考慮しているものの, 人体の変形については考慮して いない. 同様に石丸, Zhang らのモデルも人体は剛体とし て扱われている. したがって, 仮に高い衣服圧が人体に 加わった場合でも人体が変形することがないため, 衣服 の種類や部位によっては衣服圧の推定精度が十分でない 可能性がある. それに対して本研究では, 人体に対して も粒子系モデルを適用し, 外力による人体の変形を表現 する，そのため, 衣服圧を高い精度で推定することが可 能と考えられる.

以上の理由から本研究では衣服と人体を粒子系モデル で表現し，衣服圧を推定する手法を提案する．本稿では， 粒子系モデルによる衣服圧の推定方法について示し, 精 度の検証, さらに応用例として屈曲動作に伴う人体腕部 の動的衣服圧変化を推定した結果について報告する。

\section{2. 理 論}

シミュレーションにより衣服圧を推定するためには, 布および人体の力学モデル, さらに布と人体との間のイ ンタラクションを表現する衝突・反発・摩擦モデルが必 要になる。ここではそれらの数理モデル，および衣服圧 の推定方法について記述する.

\section{1 布の力学モデル[17]}

本研究では粒子系モデルにより布の力学挙動を表現す る. 粒子系モデルでは Fig. 1のように格子状に配置され た粒子(質点)において，隣接する粒子間に重力等の外力 と, 伸張応力, 曲げ応力, せん断応力の内力に相当する



(a) Particle model

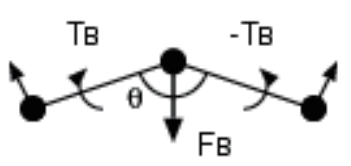

(c) Bend



(b) Stretch/Compression

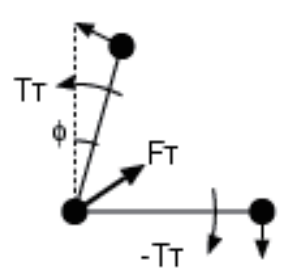

(d) Trellis
Fig. 1 Representation of cloth using particle model.
相互作用力を定義し, 質点ごとに式(1)の運動方程式を解 くことによって布の変形挙動を表現する.

$$
m_{i} \frac{d \mathbf{v}(t)}{d t}+c \mathbf{v}_{i}(t)=\mathbf{F}_{i}^{i n}(t)+\mathbf{F}_{i}^{e x}(t)
$$

ここで, $m_{i}$ は粒子 $i$ の質量, $\mathrm{V}_{i}(t)$ は時刻 $t$ における粒子 $i$ の速度, $c$ は粘性係数, $\mathbf{F}_{i}^{i n}, \mathbf{F}_{i}^{e x}$ はそれぞれ粒子 $i$ に働く 内力, 外力である. また, KES 試験から求めた布の力学 特性を变形回復応力関数として定義し, 式(1)の内力 $\mathbf{F}_{i}^{i n}$ に反映させることにより, 素材による変形挙動の違いを 再現した。

\section{2 人体の力学モデル}

近年では計測技術の発展に伴い, 距離画像デー夕によ る人体形状の取得 $[21]$, モーションキャプチャによる動 作の取得 [22]が容易に行なえる状況にある. しかしなが ら, 人体の力学挙動を正確に再現するためには, 人体の 表面形状・動作に加え, 骨格や皮下組織などの幾何形状, さらに軟部組織の硬さ等の生体力学特性を知る必要があ る. そこで本研究では, ボクセルで表現された数值人体 モデルを利用し, ボクセルの頂点に粒子を配置し, 布モ デルと同様に隣接する粒子間に相互作用力を定義するこ とにより人体の変形挙動を表現する.

Fig. 2(a) は独立行政法人通信情報研究機構を中心とし たグループによって開発された数值人体モデルである [23]. モデルは全身が約 4434 万個のボクセルにより構成 されており,さらに各ボクセルには人体組織ごとに組織 番号が割り振られている. 本研究では Fig. 2(b)のように ボクセルの頂点に粒子を配置し, ボクセルの稜線および 対角線上で隣接する粒子間に式(2)の弾性力を定義するこ とにより人体の力学挙動を表現する.

$$
\mathbf{F}_{i}^{e}(t)=\sum_{j=1}^{n} k_{i j}\left(\left\|\mathbf{x}_{i}(t)-\mathbf{x}_{j}(t)\right\|-l_{i j}\right) \frac{\mathbf{x}_{i}(t)-\mathbf{x}_{j}(t)}{\left\|\mathbf{x}_{i}(t)-\mathbf{x}_{j}(t)\right\|}(2)
$$

ここで, $\mathbf{F}_{i}^{e}$ は粒子 $i$ に作用する弾性力, $\mathbf{X}_{i}$ は粒子 $i$ の位 置, $\mathbf{X}_{j}$ は隣接する粒子 $j$ の位置, $k_{i j}$ は粒子 $i \cdot j$ 間の弾性 定数, $I_{i j}$ は粒子 $i \cdot j$ 間の初期長, $n$ は隣接する粒子 $j$ の個 数である.

なお， $k_{i j}$ は人体軟組織の硬さに相当する定数であり， 接触インピーダンス式硬度計測 $[24,25]$ 等から決定するこ とが可能である. また, 骨部については剛体として近似

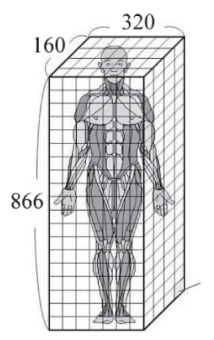

(a) Whole-Body voxel model

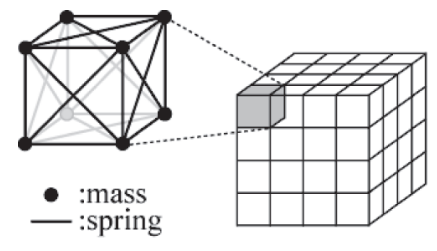

(b) Particles arrangement
Fig. 2 Representation of human body using voxel model [23]. 
し, 該当するボクセルにおける粒子の相対位置を不変と する.

\section{3 衝突・反発・摩擦モデル}

本研究では, 粒子(質点)を頂点とする三角形要素を用 いて布および人体の形状を離散近似している，そのため， 布同士の自己衝突, および布と人体の衝突は, 三角形要 素同士の衝突・反発・摩擦現象として考えることが可能 である．筆者らは既にこれらのモデルについて提案を行 なっており [26], 本研究においても同様の衝突・反発・ 摩擦モデルを用いる. 衝突モデルの実装に当たっては衝 突の瞬間のみ物体表面を連続体(三角形要素) と近似し, 三角形要素同士の衝突判定・衝突点検出を行ない, 衝突 点における相対速度の法線方向成分から衝突力 (撃力) を 計算する. 反発モデルでは衝突力が加わった際の三角形 要素の速度 ·角速度から反発力を算出する. また, 摩擦 モデルでは衝突点における相対速度の接線方向成分から クーロン摩擦力を算出する. 以上の処理により算出され た反発力と摩擦力は, 式(1)における外力 $\mathbf{F}_{i}^{e x}$ の一部とし て各質点に反映される.

一般に衝突・接触のモデルとしては, ペナルティ法 [27,28], 撃力ベース法[29], 制約ベース法[30,31]等が知 られており, 本研究のモデルは撃力ベース法に分類され る. 撃力ベース法は, 衝突を撃力により表現しているた め, ペナルティ法等に比べ正確なシミュレーションが可 能である。

\section{4 衣服圧の推定方法}

本研究では布モデルと人体モデルが接触した際の人体 モデル表面の法線方向に作用する力 (内力 $\mathbf{F}_{i}^{i n}$ と外力 $\mathbf{F}_{i}^{e x}$ の 法線方向成分) から衣服圧を推定する. シミュレーション への実装では, 布モデルおよび人体モデルの表面を三角 形要素によって表現しているため, 接触状態にある三角 形要素を特定し, 布モデルの三角形要素から人体モデル の三角形要素へ加わる力を求める必要がある. 三角形要 素同士の接触では, Fig. 3 のように点と面 (以下, 点/面接 触と略す), あるいは辺と辺 (以下, 辺/辺接触と略す)が接 触する可能性があることから，ここでは点/面接触および 辺/辺接触における圧力の算出方法について述べる.さら に, 撃力ベースのシミュレーションにおいて発生する数 值振動の影響を考慮した圧力の補正方法についても提案 する.

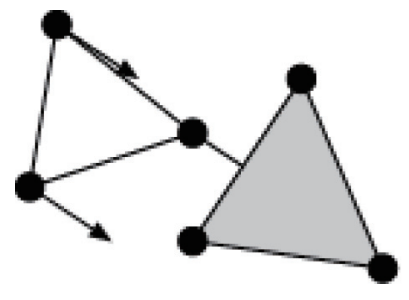

(a) Vertex/Face contact

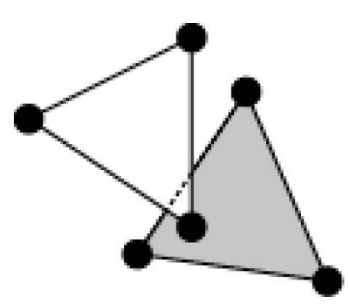

(b) Edge/Edge contact
Fig. 3 Contact type between two triangular faces.

\subsection{1 点/面接触における圧力の算出}

点/面接触の場合, Fig. 4 のように接触状態によって 2 つの状態が考えられる. 1つは Fig. 4(a)のように, 布モ デルの三角形要素(白)の頂点が人体モデルの三角形要素 (黒)の面に接触する状態であり, もう 1 つは Fig. 4(b)の ように布モデルの三角形要素の面が人体モデルの三角形 要素の頂点に接触する状態である.

Fig. 4(a)の場合は, 時刻 $t$ における布モデルの三角形要 素 A の頂点 $\mathbf{X}_{i}(t)$ と人体モデルの三角形要素 B の面との 接触を考える. 三角形要素 $\mathrm{A}$ の頂点 $\mathbf{X}_{i}(t)$ に作用している 力を $\mathbf{F}_{i}(t)$, 三角形要素 B の単位法線ベクトルを $\hat{\mathbf{n}}(t)$, 三 角形要素 B の面積を $S$ とすると, 三角形要素 B に作用す る圧力 $P$ は以下のように計算する.

$$
P(t)=\frac{\mathbf{F}_{i}(t) \cdot \hat{\mathbf{n}}(t)}{S}
$$

Fig. 4(b)の場合は, 三角形要素 A の面と三角形要素 B の頂点パーティクルとの接触を考える. 三角形要素 $\mathrm{A} の$ 各頂点 $\mathbf{X}_{i}(t), \mathbf{X}_{j}(t), \mathbf{X}_{k}(t)$ に作用している力をそれぞれ $\mathbf{F}_{i}(t), \mathbf{F}_{j}(t), \mathbf{F}_{k}(t)$ とし, 三角形要素 A における接触点を $\mathbf{P}(t)$ とする. この接触点 $\mathbf{X X}(t)$ における力 $\mathbf{F}(t)$ は, 有限 要素法における 1 次三角形要素の物理量近似と同様に形 状関数 $\left(N_{1}, N_{2}, N_{3}\right)$ を用いて式(4) から求め, 三角形要素 B に作用する圧力は Fig. 4(a)の場合と同様に式(3)により 計算する。

$$
\mathbf{F}(t)=N_{1} \mathbf{F}_{i}(t)+N_{2} \mathbf{F}_{j}(t)+N_{3} \mathbf{F}_{k}(t)
$$

\subsection{2 辺/辺 接触における圧力の算出}

辺/辺接触は, Fig. 5 に示すような頂点の接触を伴わな い三角形要素の接触である. 辺/辺接触では三角形要素 $\mathrm{A}$ の辺と三角形要素 $\mathrm{B}$ の辺を考え, 三角形要素 A が三角形 要素 B に接触している辺上の接触点 $\mathbf{X X}(t)$ における力は, 有限要素法における 1 次要素と同様に両端の粒子 $\mathbf{X}_{i}(t)$ と $\mathbf{X}_{j}(t)$ に加わる力から式(5)の直線補間により求め, 式 (3) より三角形要素 B に作用する圧力を算出する.

$$
\mathbf{F}(t)=N_{1} \mathbf{F}_{i}+N_{2} \mathbf{F}_{j}
$$

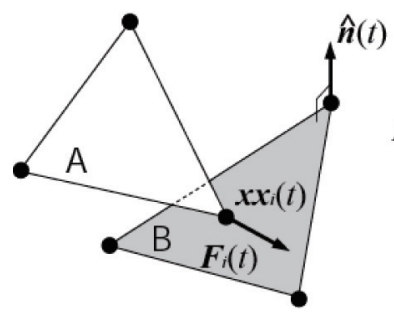

(a) Vertex $\rightarrow$ Face contact

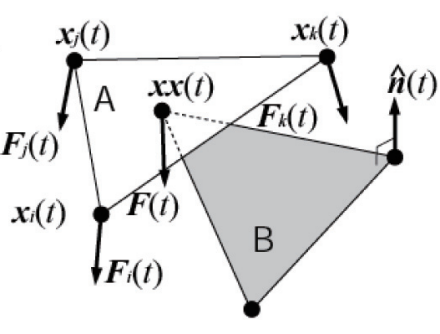

(b) Face $\rightarrow$ Vertex contact
Fig. 4 Cases on Vertex/Face contact. 


\subsection{3 数値振動を考慮した圧力の推定}

本研究では衝突処理を撃力ベースで行なっているため, 実際には布と人体が接触している場合であっても, シミュ レーションでは数值振動により断続的に非接触状態が生 じ，正確な圧力推定ができない場合がある，そこで，シ ミュレーションで得られたある時刻における圧力をそれ 以前の圧力の単純移動平均により補正を行なう. 時刻 $t$ 以前の一定時間内の接触状態において算出された圧力を $P\left(t_{1}\right), P\left(t_{2}\right), \cdots, P\left(t_{n}\right)$ とすると, 時刻 $t$ における $P(t)$ は次式より算出する.

$$
P(t)=\frac{\sum_{i=1}^{n} P\left(t_{i}\right)}{n}
$$

単純移動平均で圧力を補正することにより, Fig. 6 のよう な非接触と見なされる時間においても圧力を推定するこ とが可能になり, また, 数值的不安定により極端に高い 圧力, あるいは低い圧力が算出された場合でもその影響 を軽減する効果がある. なお, 数值振動による非接触状 態と真の非接触状態は, 一定時間内の接触の時間間隔の 分散を確認することで判別が可能である. すなわち, 数 值振動が生じている場合は時間間隔の分散が小さくなり, その場合は式(6)の圧力補正を行なう必要がある.

\section{3. 実 験}

提案したモデルを用い, 布と人体を想定した弾性体と の間に㗢く圧力をシミュレーションにより推定した。ま ず，シミュレーションの妥当性を検証するために，プリ ミティブな形状の弾性体と布の間に働く圧力をシミュ レーションにより推定し, 同一条件における実測值との
比較を行なった. その後, 検証実験の結果を踏まえ, 動 作による動的な衣服圧変化をシミュレーションにより推 定した. なお, 数值計算法には陽解法 (4 次のルンゲ・クッ 夕法)を用い, シミュレーションは Microsoft Visual C++ 2008 Express Editionにより実装し, Intel Pentium4 3.06GHz, RAM1024MB 搭載の WindowsXP PC 上で実行した.

\section{1 布と弾性物体の接触シミュレーション}

\subsection{1 シミュレーション条件}

Fig. 7 のように弾性体(ニトリル発砲ゴム)で被覆された 円柱 (アルミ製蛇腹パイプ)をポリエステル製織布で覆い, 曲率の異なる円柱表面の圧力および布の形状を推定する シミュレーションを行なった. 円柱の直径は $8.3[\mathrm{~cm}]$, 円 柱を被覆している弾性物体は $26[\mathrm{~cm}] \times 15[\mathrm{~cm}] \times 1[\mathrm{~cm}]$, 布は $11[\mathrm{~cm}] \times 30[\mathrm{~cm}]$ とし, 円柱の側面の曲率は 0 (円柱), $0.043,0.072[1 / \mathrm{cm}]$ の 3 条件とした. また, 検証実験で用 いる圧力センサの感度を考慮し, 布の両端にそれぞれ 266 [gf]の荷重を加えた. Table 1 にシミュレーションにおけ る各パラメータを, Table 2 に布モデルの面積密度および 力学特性の近似式を, Table 3 に弾性体モデルの体積密度 および力学特性を示す. なお, Table 1 の粘性係数, 反発 係数, 時間刻み幅については, 数值的不安定と, 接触処 理における「抜け(弾性物体への布の食い込み)」を避け るように経験的に決定し, 摩擦係数については, 実験で 用いた弾性物体と織布の間の動摩擦係数の計測值を与え た. また, Table 2 の布モデルの力学パラメータは, 検証 実験で用いる試料の KES 試験(カトーテック社製 KESFBI, KES-FBII) 結果を多項式近似し, それらを変形回復 応力関数とした. また, Table 3 の弾性体モデルの力学パ ラメータは, 硬度計測 (アクシム社製ビーナストロン)に より得られるセンサの押し込み荷重, 押し込み深さ, 接



Fig. 5 Cases on Edge/Edge contact.



Fig. 6 Numerical oscillation and Pressure.

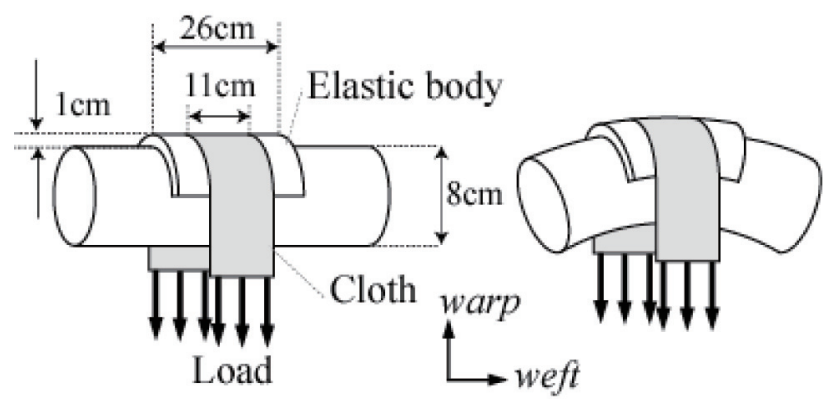

$\begin{array}{ll}\text { (a) Curvature: } 0 & \text { (b) Curvature: 0.043, 0.072[1/cm] }\end{array}$

Fig. 7 Simulation condition.

Table 1 Parameter for the simulation.

\begin{tabular}{cc}
\hline Parameter & \\
\hline Viscosity coefficient & 8.2 \\
Repulsion coefficient & 0.05 \\
Friction coefficient & 0.3 \\
Time step[s] & $10 \times 10^{-5}$ \\
\hline
\end{tabular}


触半径の結果に弾性体モデルが一致するようにパラメー 夕を最適化した。

\section{1 .2 検証方法}

検証実験では, シミュレーションと同一条件で布形状 および円柱表面の圧力を計測した。布形状は画像による 定性的な比較と, 三次元形状計測によりによる定量的な 比較を行なった. 三次元計測では布形状を対称と見なし， Fig. 8(a)に示すように布片面に $3 \mathrm{~cm}$ 間隔で 30 個の基準点 を定義し, ミノルタ社製非接触 3 次元デジタイザ VIVID 700 を用いて位置を計測した. 一方, 圧力計測ではエアパッ ク式接触圧計(エイエムアイ・テクノ社製 $\mathrm{A} 0101-\mathrm{G} 35 \mathrm{KG}$ $100 \mathrm{~K}$, センサ直径: $2 \mathrm{~cm}$ ) を用い, 円柱を被覆している弾 性物体表面の圧力を求めた。計測箇所は形状の対称性を 考慮し, Fig. 8(b)に示すように左半分における3つの断 面 $(\mathrm{A}, \mathrm{B}, \mathrm{C})$ 上の各 7 点とした。 また, 圧力の計測は各 条件で 5 回ずつ計測し, その平均值を実測值とした。

\section{2 布と人体腕部の接触シミュレーション}

着衣の動作拘束性・追従性と衣服圧の関係に着目する と, 被服設計においては静的な状態での衣服圧だけでな

Table 2 Parameters and approximation of function denoting mechanical properties for the cloth.

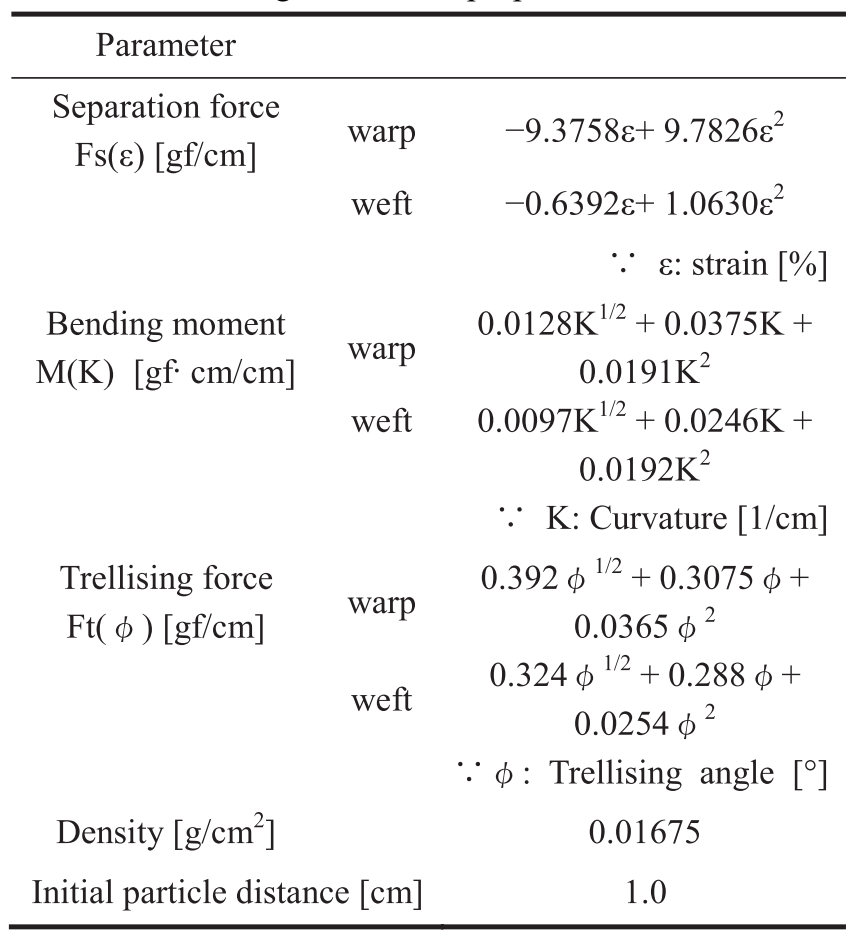

Table 3 Parameter for the elastic body.

\begin{tabular}{cc}
\hline Parameter & \\
\hline Spring constant for edge $[\mathrm{gf} / \mathrm{cm}]$ & $7.2 \times 10^{3}$ \\
Spring constant for diagonal $[\mathrm{gf} / \mathrm{cm}]$ & $2.5 \times 10^{3}$ \\
Viscosity coefficient & 6.0 \\
Density $\left[\mathrm{g} / \mathrm{cm}^{3}\right]$ & 0.1037 \\
Initial particle distance $[\mathrm{cm}]$ & 1.0 \\
\hline
\end{tabular}

く, 動作等に伴う動的な圧力変化も重要な要因であるこ とが知られている [32]. また, 粒子系モデルは動的現象 を比較的容易にシミュレートできることから，ここでは 屈曲動作に伴う衣服圧の動的変化について予測を行なっ た.

\subsection{1 シミュレーション条件}

袖に腕を通した状態をシミュレートし, 时関節の屈曲 に伴う動的な衣服圧変化を推定した(Fig. 9(a)). 袖のサ イズは長さが $30[\mathrm{~cm}]$, 周囲長が $32[\mathrm{~cm}]$ とし, 人体は 2.2 節で述べた数值人体モデルとした. Fig. 9(b)は構築した 腕部モデルの表面形状であり, Fig. 9(c)は腕内部の骨格 に相当する粒子を黒丸で示したものである. 肘の屈曲動 作を再現する際には，上腕に相当する粒子を固定し，时 を中心に前腕に相当する粒子を回転させる. シミュレー



(a) 3D measurement points for cloth (side)
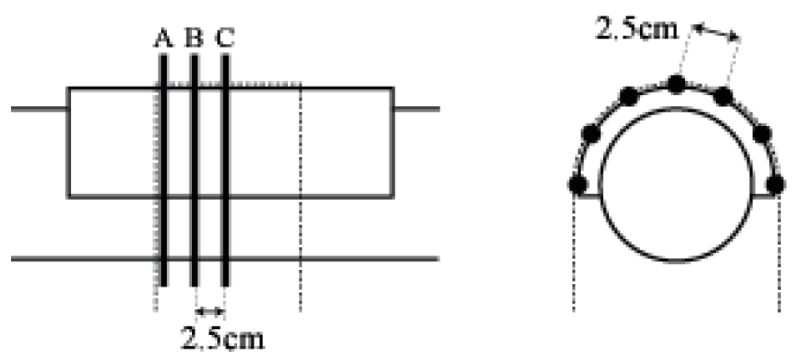

(b) Pressure measurement points (side, section)

Fig. 8 Comparison experiment.

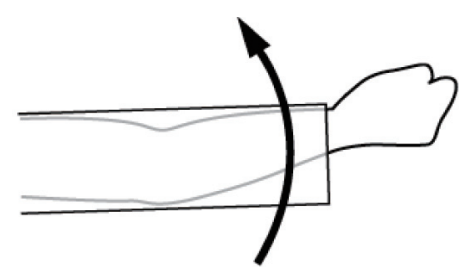

(a) Elbow flexion with clothing

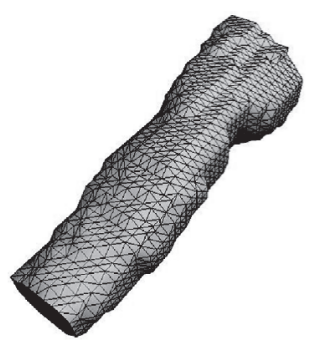

(b) Surface model

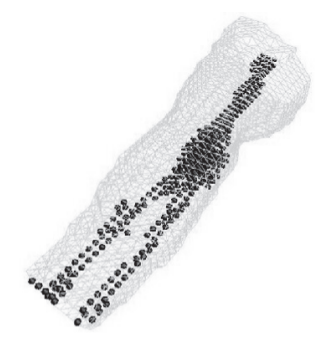

(c) Skelton model
Fig. 9 Simulation for elbow flexion. 
ションでは角速度を $45[\circ / \mathrm{s}]$ とし, 肘を伸ばした状態から 时関節角度が $60^{\circ}$ になるまで回転させた。 Table 4 に弾性 人体モデルの力学特性を示す.人体モデルのバネ定数は, 身長 $174.5 \mathrm{~cm}$, 体重 $60 \mathrm{~kg}, 23$ 歳男性の人体腕部を前節と 同様に硬度計測して求めた. シミュレーションパラメー 夕および布モデルの力学特性は前節と同一である.

\section{4. 結果および考察}

\section{1 布と弾性物体の接触シミュレーション}

曲率の異なる各条件における布(灰色) と円柱を被覆す る弾性体(黄色)の形状を Fig. 10 に示す. 左右の図はそれ ぞれ, シミュレーションおよび計測の結果であり, シミュ レーション結果については円柱を表示せず, 布と弾性物 体のみを示している. 計測結果から曲率の増加に伴い,

Table 4 Parameter for the human body.

\begin{tabular}{cc}
\hline Parameter & \\
\hline Spring constant for edge $[\mathrm{gf} / \mathrm{cm}]$ & $1.6 \times 10^{3}$ \\
Spring constant for diagonal $[\mathrm{gf} / \mathrm{cm}]$ & $0.9 \times 10^{3}$ \\
Viscosity coefficient & 2.0 \\
Density $\left[\mathrm{g} / \mathrm{cm}^{3}\right]$ & 1.0156 \\
Initial particle distance $[\mathrm{cm}]$ & 0.8 \\
\hline
\end{tabular}
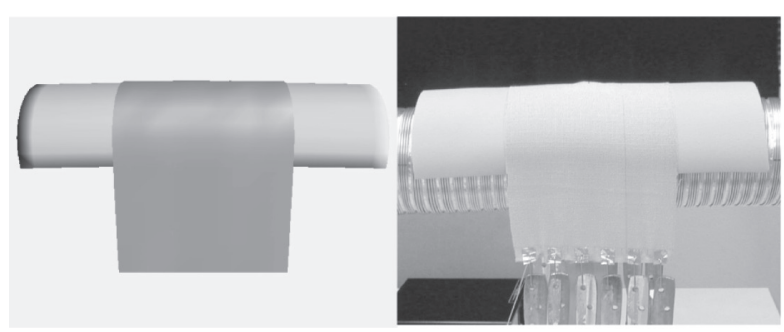

(a) Curvature: $0[1 / \mathrm{cm}]$

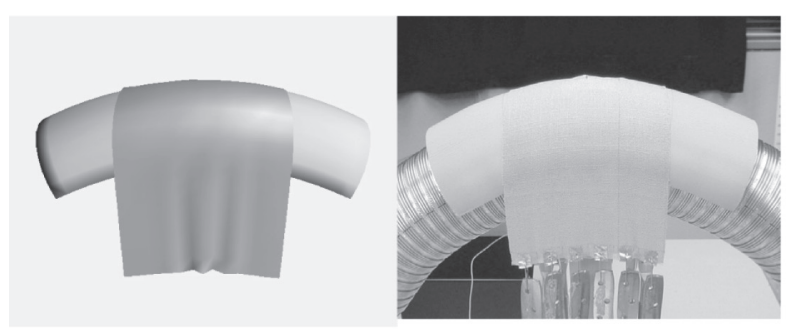

(b) Curvature: $0.043[1 / \mathrm{cm}]$



(c) Curvature: $0.072[1 / \mathrm{cm}]$

Fig. 10 Comparison of shape between simulation (left) and measurement (right).
布の垂直方向に㱀が生じ, さらに布の左右両端の中央部 では弾性物体との間に空隙が形成されることが観察され た.これらの現象はシミュレーションにおいても同様に 確認された.さらに曲率 $0.072[1 / \mathrm{cm}]$ において三次元計測 から得られた布表面上の基準点座標と, シミュレーショ ンにより推定された対応する位置座標の差をウィルクス の ムにより有意水準 5\%で検定を行なった結果, 有意差 が認められないことが確認された(Table 5). したがって, シミュレーションにより予測された形状は十分な精度を 有することが明らかになった.

次に衣服圧推定結果について検証する. Fig. 11 はシミュ レーションにより推定した弾性物体に作用している圧力 分布を曲率ごとに示したものである. 図より, 曲率 $0[1 / \mathrm{cm}]$ では比較的均一であった圧力分布が曲率の増加に伴い中 央部に集中し, その部分の圧力が増加する傾向が見られ た.これは弾性物体が凸状になるにしたがい, 弾性体の 左右両端において空隙が形成されることにより接触面積 が減少し, 結果として圧力が増加したためと考えられる.

Fig. 12 は, Fig. 11 に示した円柱中央から左側の 3 つの 断面 $(\mathrm{A}, \mathrm{B}, \mathrm{C})$ における 7 つの位置 $(-\pi / 2,-\pi / 3,-\pi / 6,0$,

Table 5 Analysis of differences in coordinate between simulation and measurement.

\begin{tabular}{cc}
\hline Statistics & \\
\hline df1 & 3 \\
df2 & 56 \\
F value & 0.046 \\
P value & 0.9865 \\
\hline
\end{tabular}

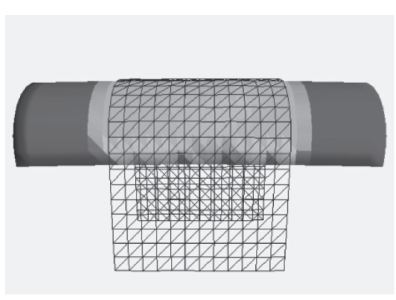

(a) Curvature: $0[1 / \mathrm{cm}]$

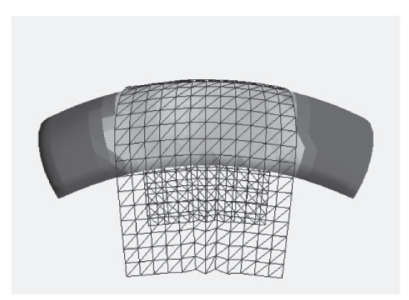

(b) Curvature: $0.043[1 / \mathrm{cm}]$

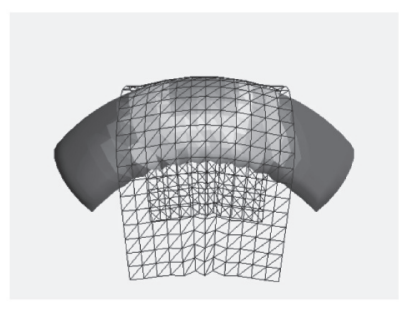

(c) Curvature: 0.072[1/cm]

$\begin{array}{lllll}0 & 0.2 & 0.4 & 0.6 & 0.8[\mathrm{kPa}]\end{array}$

Fig. 11 Pressure distribution predicted by simulation. 
$\pi / 6, \pi / 3, \pi / 2)$ での圧力を, シミュレーションと計測で比 較したものである.なお，曲率 $0[1 / \mathrm{cm}]$ においては 3 つの 断面で圧力分布が同一であるため, 断面 Cにおける結果 のみ示しており, さらに衣服圧のモデルとして知られて いる Kirk らのモデル[9]による予測結果についてもシミュ レーションの妥当性の目安として付記した.

曲率 $0[1 / \mathrm{cm}]$ の場合, 円柱の中心から $\pm \pi / 3$ の範囲では シミュレーション, 計測ともに圧力はほぼ均一であり,

シミュレーションでは平均 $0.40[\mathrm{kPa}]$, 計測では平均 0.51 [kPa]であった. また, Kirk らのモデルによると圧力は 0.46 $[\mathrm{kPa}]$ であった. 中心から $\pm / 2$ の位置においては, シミュ

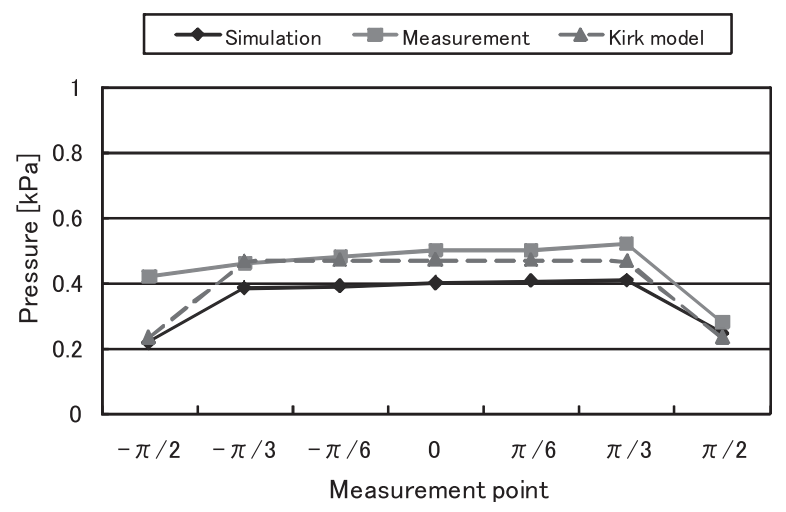

(a) Curvature: $0[1 / \mathrm{cm}]$

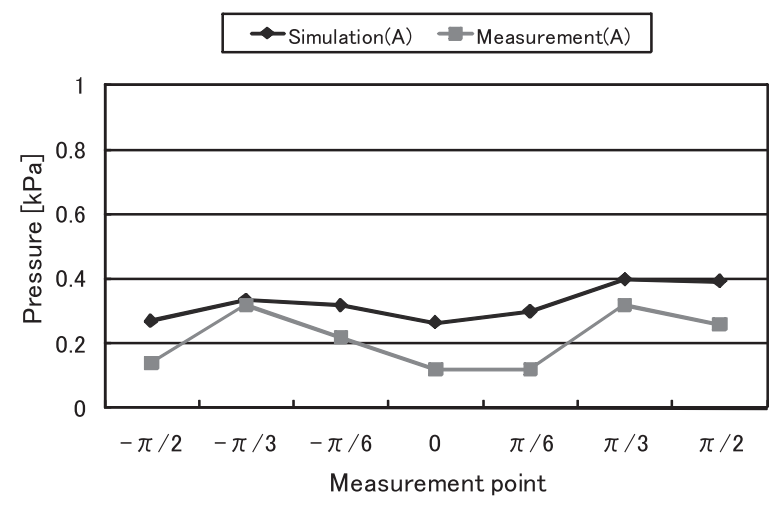

(b) Section A at Curvature: $0.042[1 / \mathrm{cm}]$

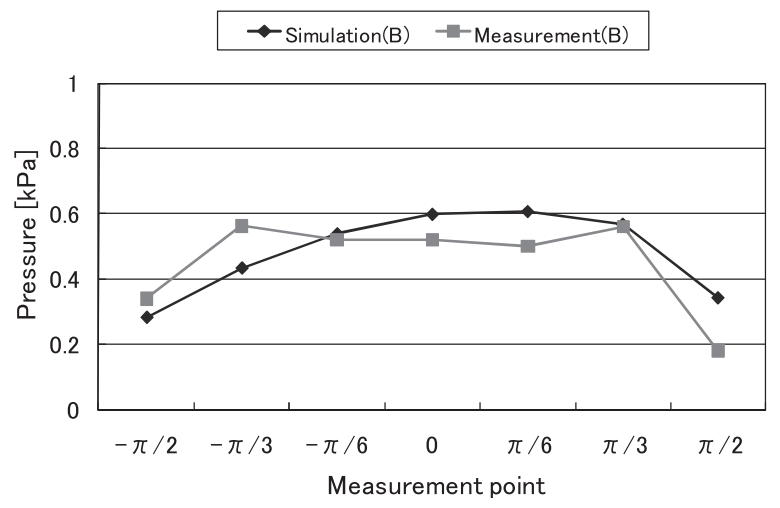

(c) Section B at Curvature: $0.042[1 / \mathrm{cm}]$

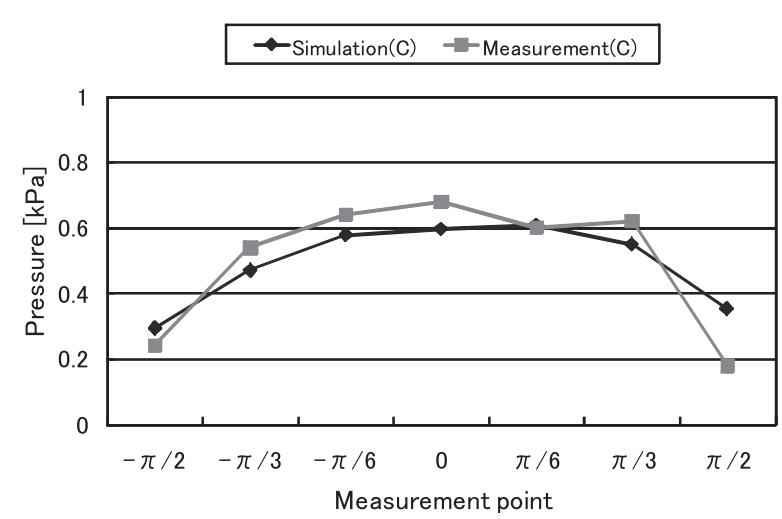

(d) Section C at Curvature: 0.042[1/cm]

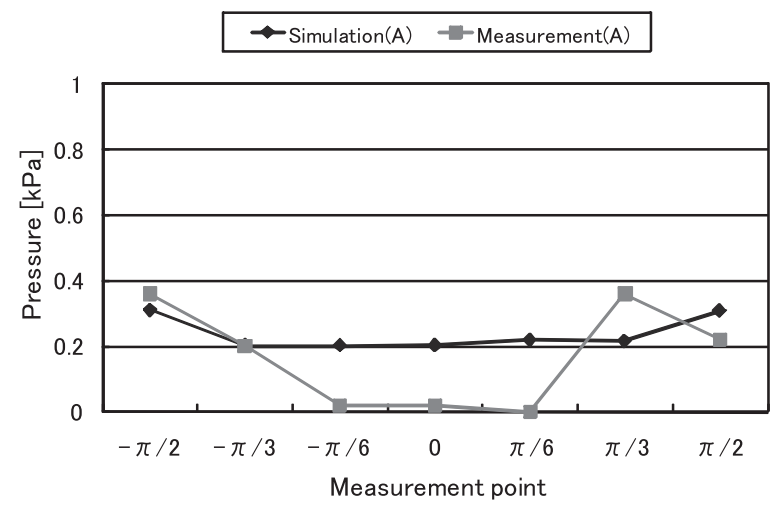

(e) Section A at Curvature: $0.072[1 / \mathrm{cm}]$

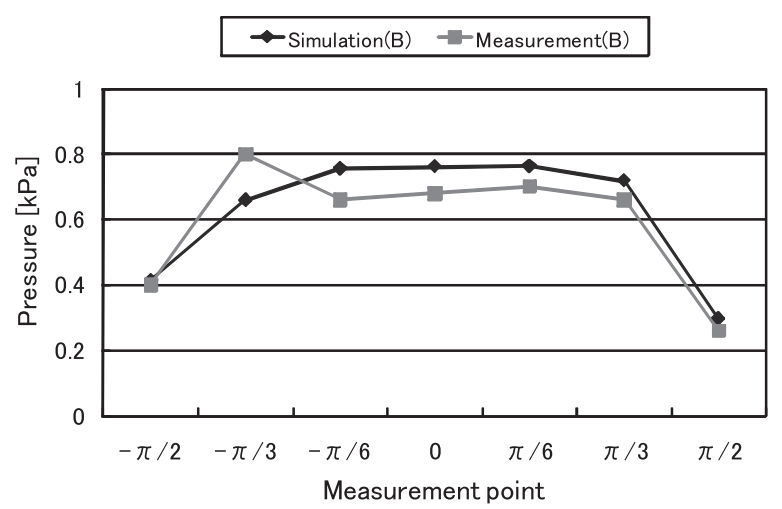

(f) Section B at Curvature: 0.072[1/cm]

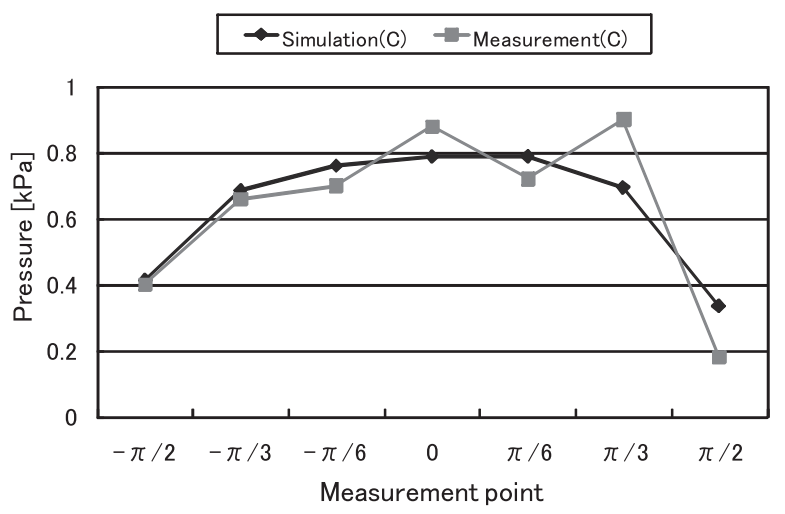

(g) Section $\mathrm{C}$ at Curvature: $0.072[1 / \mathrm{cm}]$

Fig. 12 Comparison of pressure distribution between simulation and measurement. 
レーション, 計測ともに周辺に比べ圧力が低いことが確 認された. 曲率 $0.042[1 / \mathrm{cm}]$ の場合は, 弾性物体が凸状に なるため, シミュレーション, 計測ともに断面ごとに異 なる圧力分布となった. Fig. 12(b)〜 (d)から, 相対的に 布中央部の断面 $\mathrm{C}$ の圧力が高く, 逆に端部の断面 $\mathrm{A}$ の圧 力は低い結果となった. シミュレーションと計測結果を 比較してみると, 断面 $\mathrm{A}$ においておよそ0.11[kPa]の誤差 が認められるものの, 断面 $\mathrm{B}, \mathrm{C}$ においては比較的一致し ていることが確認された.

曲率 $0.072[1 / \mathrm{cm}]$ の場合は, 曲率 $0.042[1 / \mathrm{cm}]$ の場合と 同様に中央部の断面 $\mathrm{C}$ の圧力が相対的に高く, 端部に近 づくにしたがって圧力が低下する傾向が見られた. 特に 計測の場合は, 端部の断面 $\mathrm{A} の \pm \pi / 6$ の範囲では圧力はほ ぼ 0 となっていることが確認された. シミュレーション と計測結果を比較してみると, 曲率 $0.042[1 / \mathrm{cm}]$ のと同様 に布端部の断面 $\mathrm{A}$ において比較的大きな誤差が確認され ているものの, 断面 $\mathrm{B}, \mathrm{C}$ においてはシミュレーションの 誤差が少ないことが明らかになった.

以上の結果について定量的に検証するために, シミュ レーションと計測結果について対応のある $\mathrm{t}$ 検定(両側検 定)を行なった（Table 6)．検定の結果，曲率を問わず布端 部の断面 $\mathrm{A}$ においては, シミュレーションと計測結果の 間で有意な差があることが明らかになった.つまり，布 の境界部分においてはシミュレーション結果が十分な精 度を有していないことが示唆された. 一方, 断面 $\mathrm{B}, \mathrm{C} に$ おいては両者に有意な差が認められなかったことから, 十分に布で被覆されている部分においてはシミュレー ションの精度が保証されることが示唆された.

次にシミュレーション結果について考察する. シミュ レーションでは多くの条件において, 推定された圧力が 計測值よりも低い傾向が見られた.この理由として, シ ミュレーションにおける布および弾性物体の幾何形状の 影響が考えられる. 本シミュレーションでは, 布および 弾性物体表面を三角形要素で表現し, 圧力推定の際には 接触状態にある三角形要素を特定し, 式(6)に基づき計算 を行なっている. 式(6)の分母に当たる接触面積はシミュ レーションでは弾性物体表面の三角形要素の面積に相当 し，このため三角形要素を構成する粒子間距離 (メッシュ の解像度: 本研究では, 布, 人体モデルともに $1.0 \mathrm{~cm})$ に より推定值が影響される. Fig. 13 は, メッシュ解像度が 異なる場合の接触状態を示したものである. 三角形要素 のサイズが大きい(メッシュ解像度が低い)場合, 推定さ れる圧力はその領域 (三角形要素)の平均值となり, 結果 的に計測值よりも低くなることが予想される.

同様に曲率 0.042, $0.072[1 / \mathrm{cm}]$ の断面 A におけるシミュ レーション結果の誤差についてもメッシュの解像度が原 因として考えられる.シミュレーションではこれらの位 置において布と弾性物体の間に空隙が確認されるものの, 圧力推定位置に該当する三角形要素はある程度の大きさ を有しているため, 一部でも接触が検出されると結果的
にその領域の圧力は 0 以上となる.

上記の問題を改良する方法として, メッシュ解像度を 高めることが考えられるが, メッシュ解像度は計算コス トとトレードオフの関係にあるため, 一様に解像度を高 めることは現実的ではない. したがって, 衣服圧推定の 用途応じて解像度を決定することが重要であると考えら れる。

\section{2 布と人体腕部の接触シミュレーション}

袖に腕を通した状態で肘関節を屈曲した際の, 形状お よび衣服圧の推定結果を Fig. 14 示す. 図左段の形状変化 から, 腕の屈曲に伴い时窩の周辺で布㱀が顕著になって いく様子が確認できる，また，図右段の衣服圧変化より， 布と人体が接触している部分で圧力が生じている様子が 観察され, 屈曲の初期には前腕内側に圧力が生じ, 屈曲 が進むにつれて前腕内側に加え肘頭周辺にも相対的に高 い圧力が生じている様子が確認できる. 屈曲動作を通し

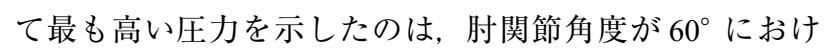

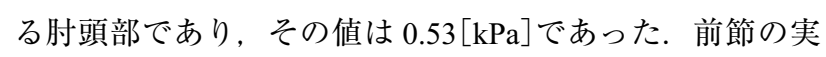

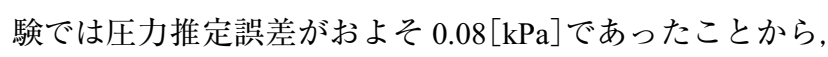
大まかな目安として时頭部に加わる圧力は $0.45 \sim 0.61$ $[\mathrm{kPa}]$ の範囲であることが推測される.

なお，シミュレーションでは肘関節の角速度を $45\left[^{\circ} / \mathrm{s}\right]$ としたが, 角速度がそれ以上に速い場合は計算が数值的 不安定になり, 結果を得ることができなかった. 動作に 伴う姿勢変化の速度は, 布の粘弾性的性質や人体と衣服 の衝突に深く関連し，ひいては動作時の快適性にも影響

Table 6 Analysis of differences in pressure between simulation and measurement $(O:$ No significant difference, $\times$ : Significant difference at $\mathrm{P}<0.01$ between simulation and measurement).

\begin{tabular}{cccc}
\hline $\begin{array}{c}\text { Section/ } \\
\text { Curvature[1/cm] }\end{array}$ & A & B & C \\
\hline 0 & & - & \\
0.042 & $\times$ & $\bigcirc$ & $\bigcirc$ \\
0.072 & $\times$ & $\bigcirc$ & $\bigcirc$ \\
\hline
\end{tabular}



(a) High resolution



(b) Low resolution
Fig. 13 Influence of mesh resolution on pressure calculation; A contact area (red) detected in the low mesh resolution (b) is larger than the high mesh resolution (a). As a result, the pressure calculated in the low mesh resolution is lower than the high resolution. 
を及ぼすと考えられる。本研究のシミュレーションにお ける数值不安定性の問題は, 数值計算における時間刻み 幅や布と人体の間の衝突処理が原因として考えられる. また, 数值解法で用いたルンゲ・クッタ法をはじめとす る陽解法は, 解が不安定になりやすいことが知られてい る.したがって, 前述の計算コストの問題に加え, 陰解 法の適用, 衝突モデルの修正を今後の課題としていきた い.

\section{5. 結 言}

本研究では粒子系モデルで表現された布および人体モ デルを用いたシミュレーションによる衣服圧推定につい て検討した。 まず静的な状態で, 曲率の異なる弾性物体 に布を懸垂させた場合の圧力をシミュレーションにより 推定したところ, 曲率の大きい場合には十分な精度を有 するものの, 曲率が 0 の場合や布端部(断面 A)において は改善の余地があることが明らかになった。この原因に ついてはモデルのメッシュ解像度 (粒子間距離)の影響が 考えられるが, 計算コストに直結する問題であるため用 途に応じた慎重な対応が必要であることが示唆された. 次に動的な状態で衣服圧を推定するために, 袖を通した 状態で肘を屈曲させるシミュレーションを行なったそそ の結果, 时の屈曲が進むにしたがい衣服圧が発生する部 位と大きさが変化していく様子を鮮明に観察できた．た だし，屈曲動作がある速度以上になると数值的不安定の ために正しい結果を得ることができなかった．この原因 としては, 数值計算における時間刻み幅や撃力・反発力 等の衝突処理, ならびに数值計算に用いた陽解法の影響 が考えられる. 今後は上記の問題点を改善することに加 え, シミュレーションの対象を全身に拡大し運動時の動 的衣服圧変化等の推定についても取り組む予定である.

\section{謝 辞}

本研究を遂行する上で不可欠な数值人体モデルデータ ベースの使用を許可して頂いた独立行政法人情報通信研 究機構, ならびにシミュレーションの実装において協力 して頂いた本学大学院修了生の佐藤賢二郎君に感謝の意 を表する. また, 本研究の一部は文部科学省グローバル $\mathrm{COE}$ プログラム「国際ファイバー工学教育研究拠点」, な らびに財団法人上田繊維科学振興会 平成 20 年度研究助成 による支援を受けた.

\section{文 献}

1. T. Nakajima, E. Kaneko, H. Shimizu, H. Gocho, and M. Muta, "Gaisetsu Hifukuzairyogaku", Tokyo, Koseikan, p.182 (1986).

2. N. Ito and M. Takeuchi, Kaseigaku Zasshi, 45, 311 (1994).
3. K. Sasaki, K. Miyashita, M. Edamura, T. Furukawa, Y. Shimizu, and H. Shimizu, Sen'i Seihin Shohi Kagaku, 38, 53 (1997).

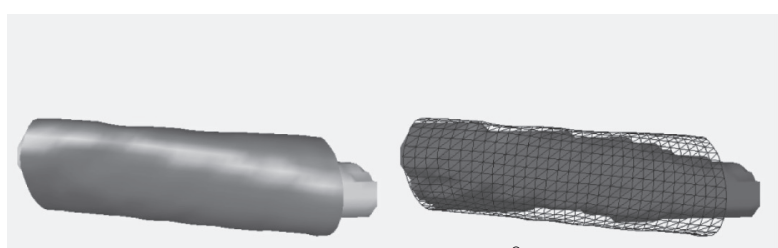

(d) Elbow angle: $0^{\circ}$

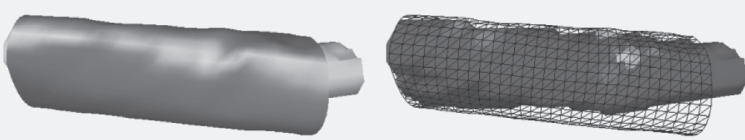

(c) Elbow angle: $8.6^{\circ}$

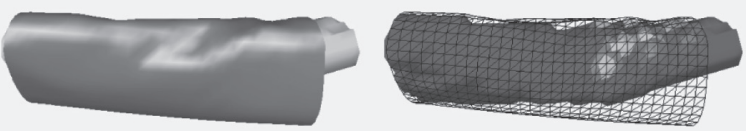

(a) Elbow angle: $17.1^{\circ}$

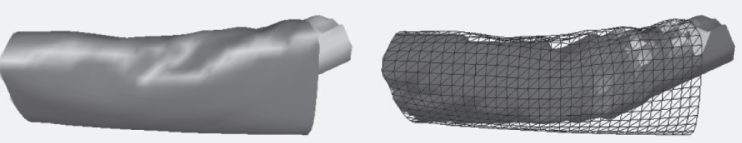

(b) Elbow angle: $25.7^{\circ}$

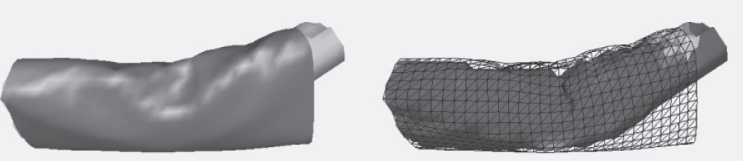

(e) Elbow angle: $34.3^{\circ}$
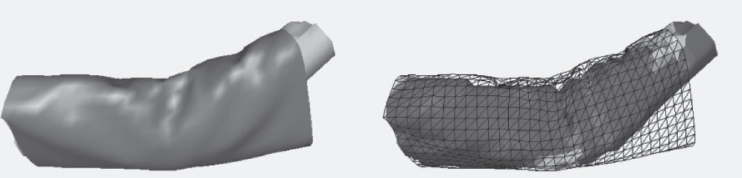

(f) Elbow angle: $42.9^{\circ}$
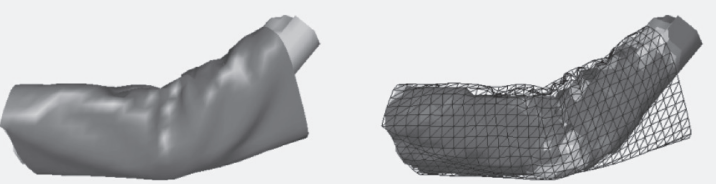

(g) Elbow angle:51.4
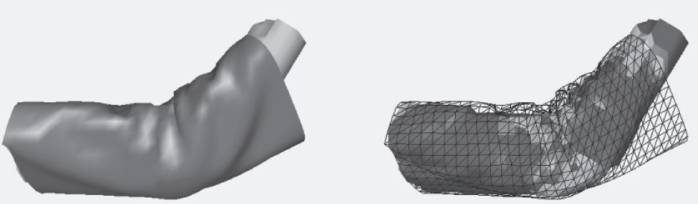

(h) Elbow angle:60.0

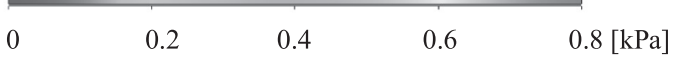

Fig. 14 Results of Simulation for elbow flexion : (left) shape, (right) pressure. 
4. H. Morooka, R. Fukuda, H. Sasaki, and H. Morooka, Sen 'i Gakkaishi, 62, 287 (2006).

5. T. Mitsuno, Sen'i Gakkaishi, 64, 419 (2008).

6. C. Shimosaka, I. Nakada, M. Ishigaki, and M. Inomata, Kaseigaku Zasshi, 59, 29 (2008).

7. H. Kanai, H. Tsuji, M. Kamijo, Y. Matsumoto, and T. Nishimatsu, Sen 'i Gakkaishi, 63, 159 (2007).

8. N. Ito, Kaseigaku Zassh, 44, 291 (1993).

9. Wm. Kirk and S. M. Ibrahim, Text. Res. J., 36, 37 (1966).

10. H. Niwaya, H. Imaoka, and A. Shibuya, Sen 'i Seihin Shohi Kagaku, 52, 99 (1996).

11. H. Niwaya, H. Imaoka, and A. Shibuya, Sen 'i Seihin Shohi Kagaku, 52, 248 (1996).

12. S. Ishimaru, Y. Isogai, M. Matsui, K. Negishi, C. Nonomura, and A. Yokoyama, J. Tex. Eng., 55, 179 (2009)

13. X. Zhang, KW. Yeung, and Y. Li, Text. Res. J., 72, 245 (2002).

14. SG. Liu, QG. Liu, T. An, JZ. Sun, and QS. Peng, Visual Computer, 25, 687 (2009).

15. A. Paiva, F. Petronetto, T. Lewiner, and G. Tavares, Computer-Aided Design, 41, 306 (2009).

16. A. Nealen, M. Muller, R. Keiser, E. Boxerman, and M. Carlson, Computer Graphics Forum, 25, 809 (2006).

17. S. Mitsui, D. Komai, X. Dai, T. Furukawa, M. Takatera, Y. Shimizu, and M. Hashimoto, J. Image Information and Television Engineers, 54, 1762 (2000).

18. S. Mitsui, S. Murakami, X. Dai, T. Furukawa, M. Takatera, Y. Shimizu, and M. Hashimoto, Technical Report of Image Information and Television Engineer, 23, 21 (1999).

19. S. Mitsui, D. Komai, X. Dai, T. Furukawa, M. Takatera, Y. Shimizu, and M. Hashimoto, Technical Report of IEICE HCS , 99, 21 (1999).
20. D. House and D. Breen, "Cloth Modeling and Animation", A K Peters, Massachusetts, p.79 (2000).

21. H. Oka and T. Irie, IEICE Trans D, J88-D-II, 1564 (2005).

22. S. Ishikawa, JK. Tan, and T. Sone, Technical Report of IEICE MI, 109, 19 (2009).

23. T. Nagaoka, K. Sakurai, E. Kunieda, S. Watanabe, H. Honma, T. Suzuki, M. Kawai, K. Sakamoto, K. Ogawa, K. Konokawa, K. Kubota, B. Kim, M. Taki, Y. Yamanaka, and S. Watanabe, Trans. Japanese Society for Medical and Biological Eng., 40, 239 (2002).

(Fig. 2 reprinted with permission from National Institute of Information and Communications Technology)

24. R. Aoyagi and T. Yoshida, Technical Report of IEICE US, 63, 67 (2003).

25. H. Oka and T. Irie, Biomechanisms, 12, 15 (1994).

26. D. Komai, S. Murakami, M. Takatera, M. Hashimoto, and Y. Shimizu, NICOGRAPH Trans., 17, 81 (2001).

27. M. Moor and J. Wilhelms, Computer Graphics, 22, 289 (1988).

28. M. McKenna and D. Zeltzer, Computer Graphics, 24, 29 (1990).

29. E. Guendelman, R. Bridson, and R. Fedkiw, $A C M$ Tansaction on Graphics, 22, Issue 3 (2003).

30. D. Baraff, SIGGRAPH'97 Course Notes, D3 (1997).

31. D. Baraff, IEEE Computer Graphics and Applications, 15, 63 (1995).

32. H. Kawabata, A. Yamagata, N. Suda, and K. Ishikawa, $J$. home economics of Japan, 44, 1033 (1993). 